\title{
Preliminary assessment of Rosmarinus officinalis toxicity on male Wistar rats' organs and reproductive system
}

\author{
Rita de Cássia da Silveira e Sá ${ }^{1 *}$, Magda N. Leite ${ }^{2}$, Leandra E.G. Oliveira ${ }^{3}$, Melina M. Toledo ${ }^{1}$, \\ Tânia C. Greggio ${ }^{1}$, Martha O. Guerra ${ }^{1}$
}

${ }^{1}$ Departamento de Biologia, Centro de Biologia da Reprodução, Universidade Federal de Juiz de Fora, 36036-900, Juiz de Fora, Brazil,

${ }^{2}$ Faculdade de Farmácia e Bioquímica, Universidade Federal de Juiz de Fora, 36036-970, Juiz de Fora, Brazil,

${ }^{3}$ Departamento de Ciências Biológicas, Universidade Estadual do Sudoeste da Bahia, 45200-000, Jequié, Brasil

\begin{abstract}
RESUMO: "Avaliação preliminar da toxicidade de Rosmarinus officinalis no sistema reprodutor e em órgãos de ratos Wistar". Alecrim (Rosmarinus officinalis L. - Lamiaceae) é uma planta utilizada no tratamento de afecções hepática, intestinal, renal e respiratória. Sua toxicidade foi investigada em ratas e seu efeito antiimplantação foi relatado em estudos prévios. Este trabalho analisa o efeito da administração aguda do extrato de $R$. officinalis em órgãos vitais, em órgãos do sistema reprodutor e na produção de espermatozóides de ratos Wistar adultos. Ratos Wistar foram tratados com $1 \mathrm{~mL}$ do extrato aquoso de $R$. officinalis na dose de $291,2 \mathrm{mg}$ e $582,4 \mathrm{mg} / \mathrm{kg}$ de peso corporal por cinco dias. O peso corporal e de órgãos, a produção de espermatozóides e o consumo de ração foram avaliados. Os resultados mostraram que a administração da dose menor do extrato de $R$. officinalis não alterou significativamente o peso corporal e de órgãos e nem interferiu com a produção de gametas. Entretanto, os animais tratados com a maior dose evidenciaram aumento significativo de peso de vesícula seminal, mas nenhuma outra alteração significativa das outras variáveis. O consumo de ração não foi afetado pelos tratamentos.
\end{abstract}

Unitermos: Rosmarinus officinalis, órgãos reprodutivos, produção de espermatozóides, rato Wistar.

\begin{abstract}
Rosemary (Rosmarinus officinalis L. - Lamiaceae) is a shrub used in the treatment of hepatic, intestinal, renal and respiratory affections. Its toxicity was assessed in female rats and an anti-implantation effect was reported after treatment with this plant. This work analyzes the effect of the short-term administration of $R$. officinalis extract on vital organs, on the organs of the reproductive system and sperm production of mature male Wistar rats. Adult Wistar rats were treated with $1 \mathrm{~mL}$ of $R$. officinalis aqueous extract at a dose level of $291.2 \mathrm{mg}$ and $582.4 \mathrm{mg} / \mathrm{kg}$ of body weight for five days. Body and organs weights, sperm production and food consumption were evaluated. The results showed that the lower dose administration of $R$. officinalis extract did not significantly alter body and organs weight nor did it interfere with gamete production. However, animals treated with the higher dose showed significant weight increase of the seminal vesicle but no significant alteration of the other variables. Food intake was not affected by the treatments.
\end{abstract}

Keywords: Rosmarinus officinalis, reproductive organs, sperm production, Wistar rats.

\section{INTRODUCTION}

Medicinal plants have long been used by the peoples of the world for treating their illnesses, but many substances found in them may be harmful to the organism. A large number of plants are known for their teratogenic and abortive properties (Keeler, 1990; Norton, 1996; Mengue et al., 2001) or for their toxic effect on the male reproductive system (Soufir et al., 1989).

There are a number of agents that can have an adverse effect on the male reproductive system, for example by interfering with sexual maturation, the production, and transport of spermatozoa, the spermatogenic cycle, sexual behavior and fertility (Kimmel et al., 1995). The action of a toxic agent in the testis may cause a reduction in the sperm concentration and the production of abnormal gametes (Sundaram; Witorsh, 1995). It may also play an adverse role on the Leydig cell, affecting testosterone production (Mooradian et al., 1987). Various studies have reported the toxic effect of agents in the epididymis (Tsunoda; Chang, 1976; Working et al., 1985a,b; Klinefelter et al., 1990; VieiraFilho et al., 2002), by disturbing the sperm maturation process, and the functioning of the accessory sex glands 
(Zenick et al., 1994).

Rosmarinus officinalis L., popularly known as rosemary, is a perennial bush of the family Lamiaceae employed in folk medicine for treating hepatic, intestinal, renal and respiratory affections. It is also known for its emmenagogue, colagogue, antispasmodic activities (Camargo, 1985; Santos, et al., 1988; Lemonica et al., 1996; Al-Sereiti et al., 1999; Martins et al., 2000; Tôrres et al., 2005) and as an abortifacient (Laszlo; Henshaw, 1954; Watt; Breyer-Branwijk, 1962). Pharmacological investigations have shown that the aqueous extract of $R$. officinalis possess diuretic effect in rats (Haloui et al., 2000); the methanolic extract inhibits the motility of Tripanosoma cruzi epimastigots (Abe et al., 2002), the hydroalcoholic extract exhibits anti-ulcerogenic (Dias et al., 2000) and hepatoprotective activities (Hoefler et al., 1987; Fahim et al., 1999; Sotelo-Félix et al., 2002, Amin; Hamzer, 2005), antimicrobial activity (Lima et al., 2006 ), inhibitor of $\alpha$-amylase activity (Funke; Melzig, 2006), inhibitor of the enzyme acetylcholinesterase (Barbosa-Filho et al., 2006) and inhibits skin (Huang et al., 1994) and mammary (Singletary; Nelshoppen, 1991) tumorigenesis.

Phytochemical studies revealed the presence of several compounds in $R$. officinalis including phenolic diterpenes (Thorsen; Hildebrandt, 2003) such as carnosol and carnosic acid (Aruoma et al., 1992), diterpenoid quinines (Mahmoud et al., 2005), rosmarinic acid (Maris; Giovanni, 1958), flavonoids (Guilbert; Bezanger, 1970), rosmaricine (Yakhontova; Kuzovkov, 1963) and essential oils (Dmitriev et al., 1988). Carnosol, carnosic acid and rosmarinic acid were found to possess strong antioxidative activity whereas essential oils showed antimicrobial (Larrondo et al., 1995; Mangena; Muyima, 1999) and antifungic activities (Larrondo et al., 1995). Flavonoids have been shown to produce antiandrogenic activity and affect fertility in male dogs (Bhargava, 1989).

Previous studies have investigated $R$. officinalis actions on the female reproductive system. Damasco and Lemonica (1999) reported a high incidence of anomalous embryos in rats treated with $260 \mathrm{mg} / \mathrm{kg}^{-1}$ of rosemary ethanolic extract from the first to the fourth day of gestation. A higher dose $\left(1040 \mathrm{mg} / \mathrm{kg}^{-1}\right)$ administered during the same period reduced the number of blastocysts found in the uterus. After continuous administration from the first to the sixth day and from the sixth to the fifteenth day of gestation, Lemonica et al. (1996) reported the embryotoxic effect on the pre-implantation period and the absence of any significant developmental alteration after this period. It was suggested that the embryotoxic effects, which led to implantation impairment, were due to morphological alterations in the embryos, hormonal alterations or reduction of motility in the oviduct.

Considering the presence of substances with antifertility activity, its toxic effect on the female reproductive system, and the fact that no information has been found in the literature about the effects of $R$. officinalis on the male reproductive system, this preliminary work had the purpose of investigating the effects of the short-term exposure to $R$. officinalis on vital organs, the reproductive system, and sperm production of the Wistar rat. Short-term tests are of value in the identification of target sites, affected cells, and mechanisms of toxicity (Zenick et al., 1994).

\section{MATERIAL AND METHODS}

\section{Plant material and extraction}

$R$. officinalis L. was collected in the botanical garden of the Pharmacy and Biochemistry Faculty, Universidade Federal de Juiz de Fora (UFJF), Juiz de Fora, MG, Brazil, and authenticated by Dr. Fátima Regina Gonçalves Salimena in the Herbarium Leopoldo Krieger, Department of Botany, (UFJF), where a voucher specimen registered under the number CESJ 45407 is deposited. The aqueous extract was prepared using aerial parts of this plant. Dried and powdered aerial parts underwent maceration for 24 hours followed by exhaustive percolation. On both processes distilled water was used as the extractor fluid. After percolation, the material was transferred to a rotavapor in order to reduce the water volume and obtain the final concentration $(72.8$ $\mathrm{mg} / \mathrm{mL}$ ) of the extract.

\section{Animals}

Ninety-day-old adult male Wistar rats (Rattus norvegicus Berkenhout, 1769), weighing around $250 \mathrm{~g}$, were obtained from the vivarium of UFJF, where they were born and bred. They were housed individually under standard laboratory conditions with a $12 \mathrm{~h}$ light/12 h dark photoperiod. They were fed on rat chow pellets and received water ad libitum. Animal care and the experimental protocol followed the principles and guidelines suggested by the Brazilian College of Animal Experimentation (COBEA) and were approved by the Ethical Committee of the Federal University of Juiz de Fora (UFJF) (protocol number 003/2004 - CEA).

\section{Experimental procedure}

The rats were randomly distributed into three treatment groups (T1, T2 and $\mathrm{T} 3$ ) and their respective control groups ( $\mathrm{C} 1, \mathrm{C} 2$ and $\mathrm{C} 3$ ), and were submitted to the 2.5-week reproductive toxicity test protocol described by Linder et al. (1992). Each animal from the treatment groups T1 and T2 received, by gavage and once daily, 1 $\mathrm{mL}$ of the $R$. officinalis aqueous extract at a dose level of $291.2 \mathrm{mg} / \mathrm{kg}$ of body weight for five days whereas animals from the group T3 were treated with twice the dose $(582.4 \mathrm{mg} / \mathrm{kg}$ of body weight). The control groups received $1 \mathrm{~mL}$ of distilled water, following the same protocols as the treatment groups. 


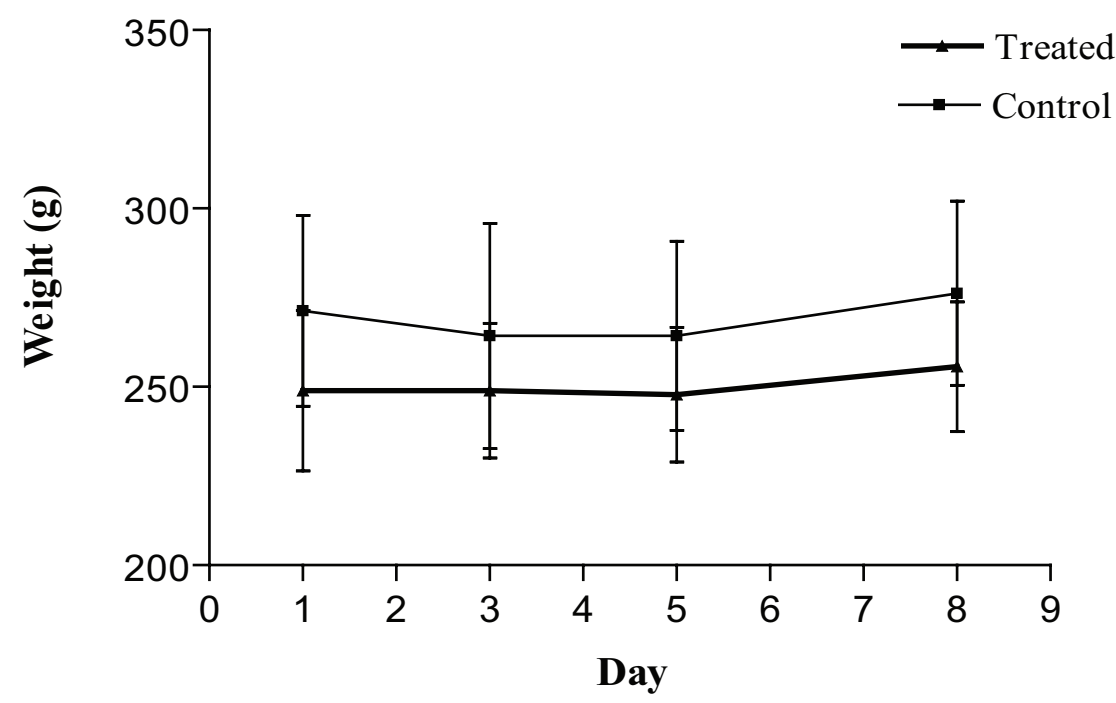

Figure 1. Body weight of control and R. officinalis- treated Wistar rats during exposure of five days and death at three days after the end of treatment $(291.2 \mathrm{mg} / \mathrm{kg}$ of body weight; Control $\mathrm{N}=10$, Treated $\mathrm{N}=11$ ).

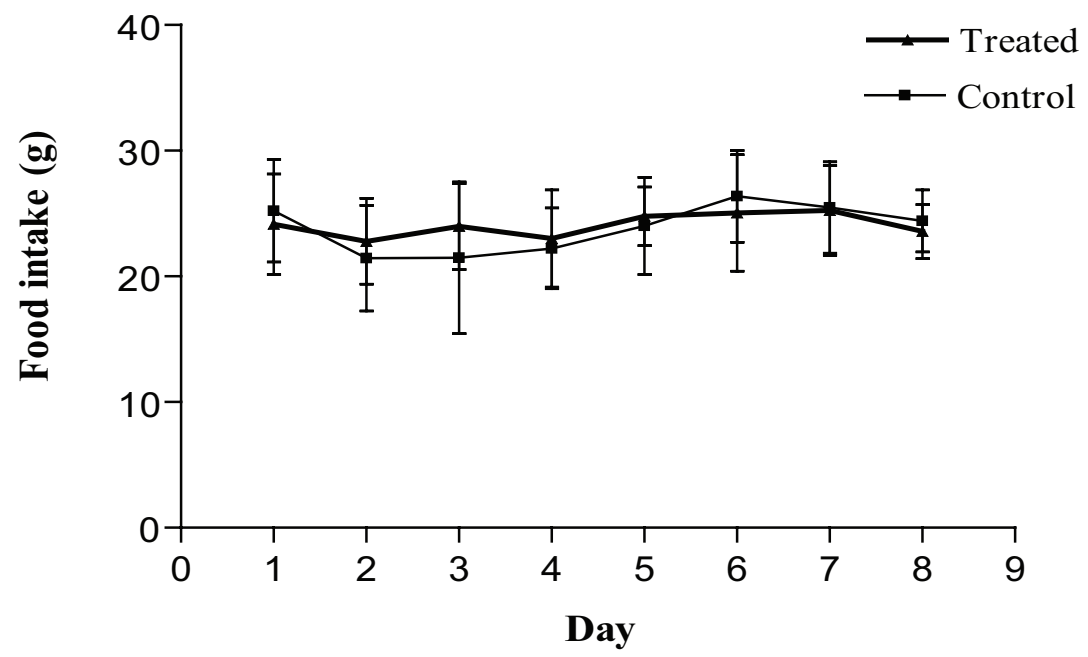

Figure 2. Daily food consumption of control and R. officinalis- treated Wistar rats during exposure of five days and death at three days after the end of treatment $(291.2 \mathrm{mg} / \mathrm{kg}$ of body weight; Control $\mathrm{N}=10$, Treated $\mathrm{N}=11$ ).

During the experiment, the animals were inspected daily for detection of clinical signs of toxicity, such as piloerection, and alterations in locomotor activity (Mason; Kang, 1994). Body weight was recorded before the beginning of treatment, every two days and at the end of treatment. Food consumption was monitored daily. The animals were killed by an overdose of anesthetic three (groups C1 and T1, C3 and T3) and 14 days (groups $\mathrm{C} 2$ and T2) after the end of treatment. Immediately after death, the animals underwent laparotomy for removal and posterior weighing of the following organs: testes, left epididymis, seminal vesicle, prostate, liver, kidneys, lungs, brain and pituitary gland.

Sperm were collected from the epididymal secretion of the right epididymis cauda. The secretion was placed in a $0.3 \mathrm{~mL}$ drop of physiological serum and later diluted in distilled water. From this homogenate, a sample was taken and the number of sperm counted using a hemocytometer with improved double Neubauer ruling (Moraes, 1994). 


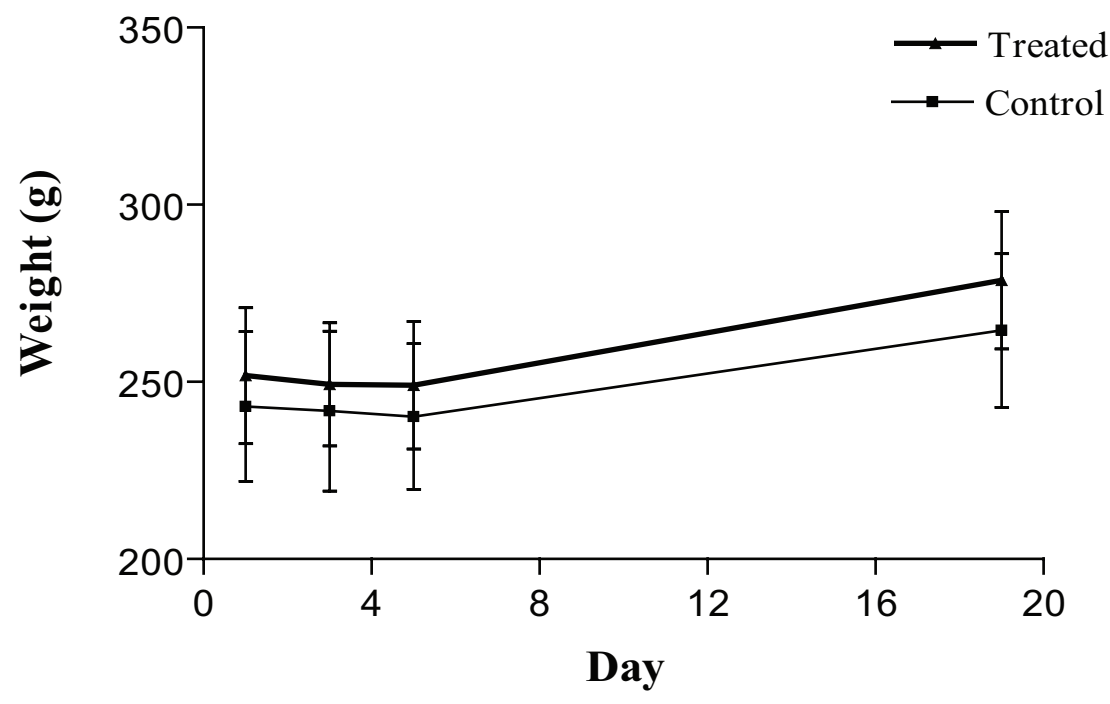

Figure 3. Body weight of control and R. officinalis- treated Wistar rats during exposure of five days and death at 14 days after the end of treatment $(291.2 \mathrm{mg} / \mathrm{kg}$ of body weight; Control N=12, Treated $\mathrm{N}=10)$.

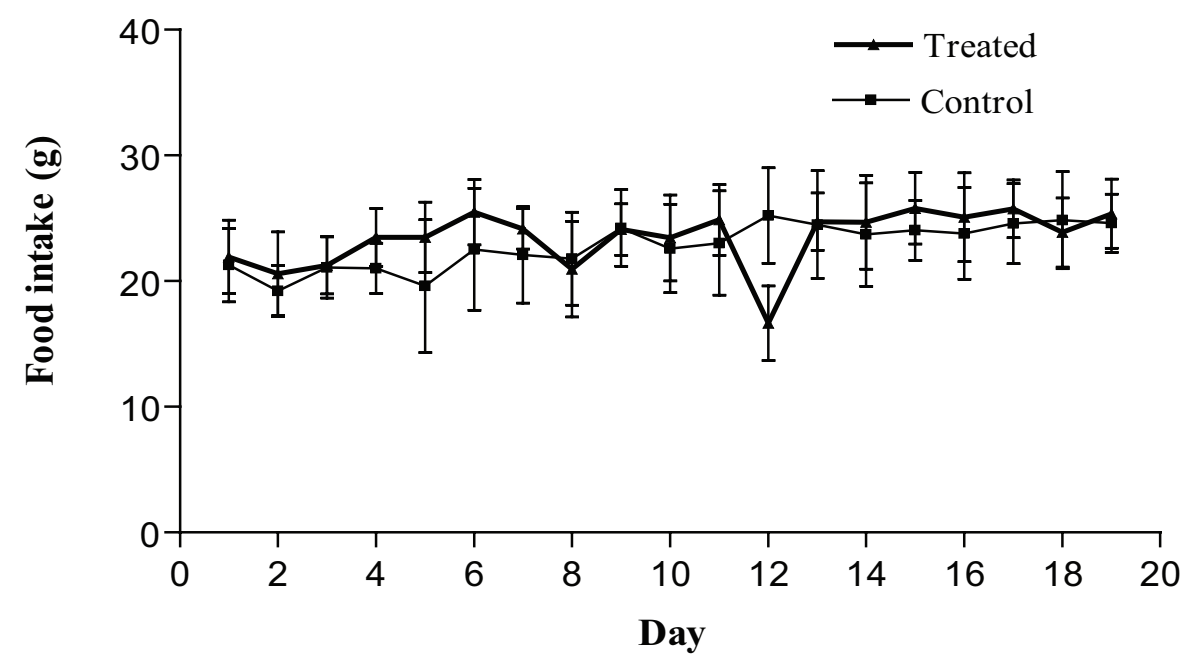

Figure 4. Daily food consumption of control and $R$. officinalis- treated Wistar rats during exposure of five days and death at 14 days after the end of treatment $(291.2 \mathrm{mg} / \mathrm{kg}$ of body weight; Control $\mathrm{N}=12$, Treated $\mathrm{N}=10$ ).

\section{Statistical analysis}

The data were analyzed using the Student's $t$ test and the Mann-Whitney test $(\alpha=0.05)$ (Sokal; Rohlf, 1995) and were expressed by mean and standard deviation (SD).

\section{RESULTS AND DISCUSSION}

The diverse therapeutic properties of $R$. officinalis has incremented its use by the population (Ruppelt et al., 1990; Cruz et al., 1996), however the presence of chemical compounds, such as flavonoids, that have been reported to have toxic (Bhargava, 1989; Ulubelen et al., 1994; Born et al., 2000) and antifertility activities (Vilegas et al., 1997; Martins et al., 2000) as well as the anti-implantation effect reported on female rats (Lemonica et al., 1996) suggests a potential reproductive toxic role of this plant. 


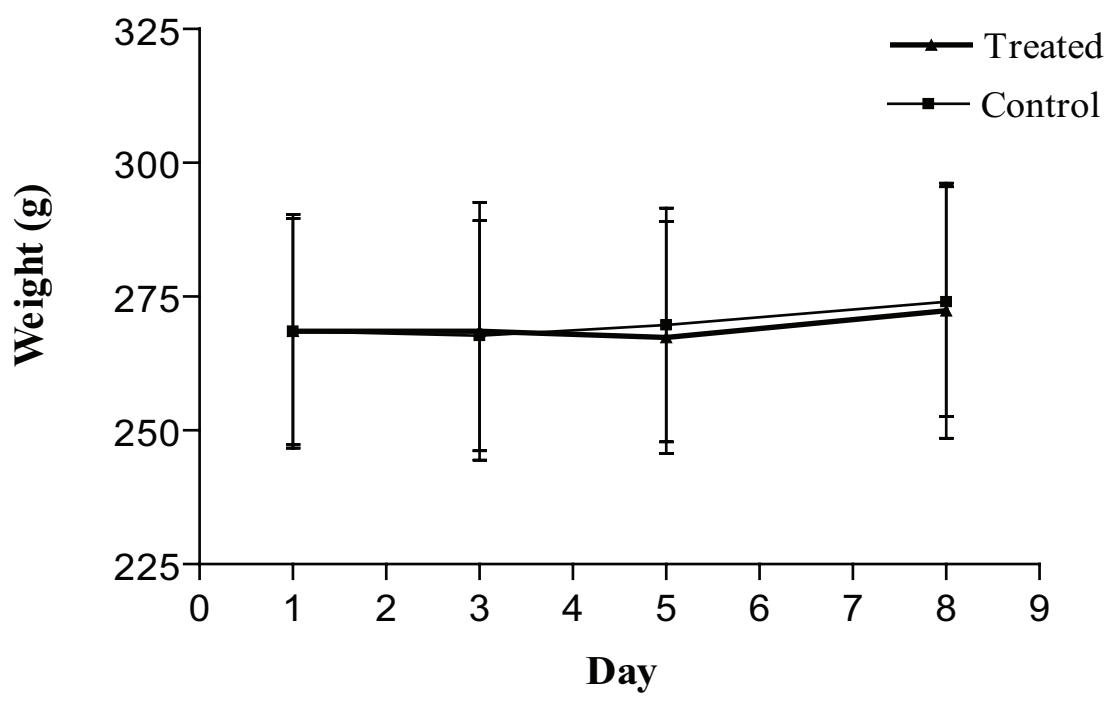

Figure 5. Body weight of control and $R$. officinalis- treated Wistar rats during exposure of five days and death at three days after the end of treatment $(582.4 \mathrm{mg} / \mathrm{kg}$ of body weight; Control $\mathrm{N}=12$, Treated $\mathrm{N}=12$ ).

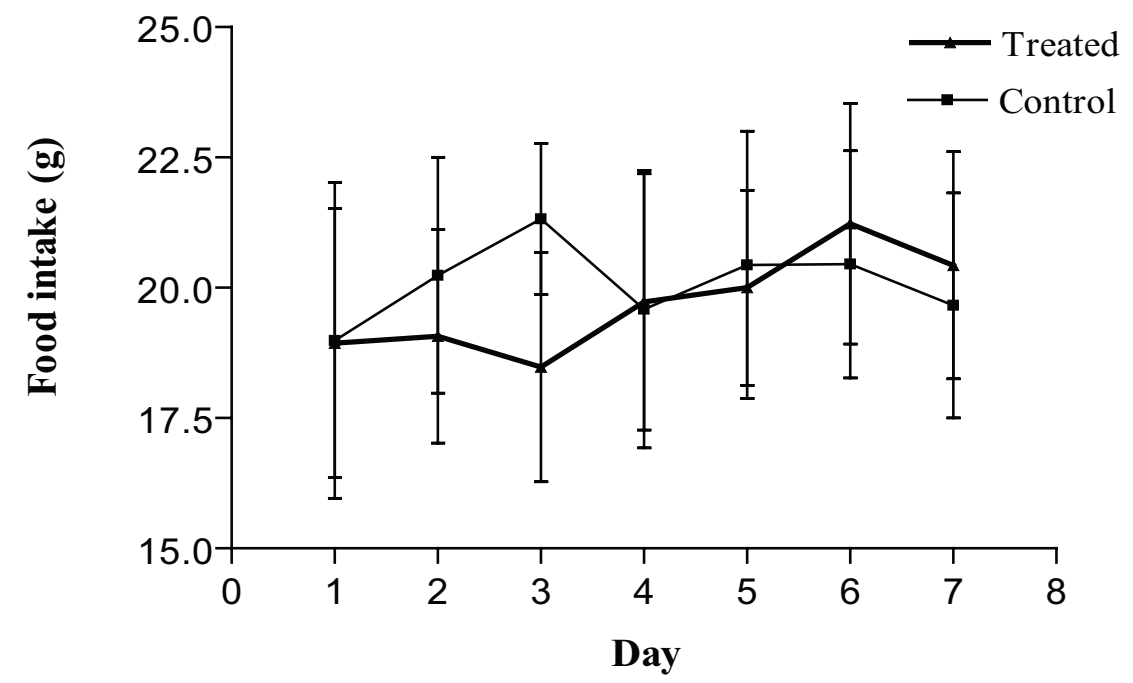

Figure 6. Daily food consumption of control and R. officinalis- treated Wistar rats during exposure of five days and death at three days after the end of treatment $(582.4 \mathrm{mg} / \mathrm{kg}$ of body weight; Control $\mathrm{N}=12$, Treated $\mathrm{N}=12$ ).

This study was carried out to make a preliminary investigation of $R$. officinalis toxicity by the use of short duration protocols as they are useful tools for identifying compounds with potential to affect the male reproductive system and spermatogenesis (Chan; Hayes, 1994; Linder et al., 1990, 1992, 1994), allowing the identification of target organs, affected cells and the toxicity mechanisms of compounds (Clegg et al., 2001). These are important approaches for assessing male reproductive risk, and, according to Zenick et al. (1994), such delineation may be impossible after subchronic treatment. In this work, adult male Wistar rats were submitted to a short-term exposure to $R$. officinalis aqueous extract at a dose level 9 times $(291.2 \mathrm{mg} / \mathrm{kg}$ of body weight) and 18 times $(582.4$ $\mathrm{mg} / \mathrm{kg}$ of body weight) greater than the human dose.

During the experimental procedure, no deaths, locomotor activity alteration, piloerection or any other clinical signs of toxicity such as were observed in any of the groups. Body weight did not change significantly (Figures 1,3 and 5) and the treatment did not interfere 
Table 1. Weights of vital and reproductive organs of control and Rosmarinus officinalis-treated adult male Wistar rats during exposure of five days and death at three days after the end of treatment

\begin{tabular}{l|l|l}
\hline \multirow{2}{*}{ Weights } & \multicolumn{2}{c}{ Groups (g) } \\
\cline { 2 - 3 } & Control & Treated \\
\hline Brain & $1.09 \pm 0.06$ & $1.08 \pm 0.11$ \\
Pituitary gland (mg) & $8.60 \pm 0.70$ & $7.82 \pm 0.87$ \\
Liver & $11.22 \pm 0.87$ & $10.48 \pm 1.34$ \\
Right kidney & $1.11 \pm 0.11$ & $1.01 \pm 0.07$ \\
Left kidney & $1.07 \pm 0.10$ & $1.08 \pm 0.11$ \\
Lung & $1.42 \pm 0.15$ & $1.33 \pm 0.18$ \\
Right testis & $1.39 \pm 0.09$ & $1.31 \pm 0.07$ \\
Left testis & $1.39 \pm 0.08$ & $1.30 \pm 0.06$ \\
Left epididymis & $0.44 \pm 0.01$ & $0.45 \pm 0.03$ \\
Prostate & $0.25 \pm 0.03$ & $0.23 \pm 0.05$ \\
Seminal vesicle & $0.31 \pm 0.03$ & $0.31 \pm 0.02$ \\
\hline
\end{tabular}

Results are expressed in mean \pm S.D. $\mathrm{P}>0.05$. (Control $\mathrm{N}=10$; Treated $\mathrm{N}=11)$

Table 2. Weights of vital and reproductive organs of control and Rosmarinus officinalis-treated adult male Wistar rats during exposure of five days and death at 14 days after the end of treatment

\begin{tabular}{l|l|l}
\hline \multirow{2}{*}{ Weights } & \multicolumn{2}{c}{ Groups $(\mathrm{g})$} \\
\cline { 2 - 3 } & Control & Treated \\
\hline Brain & $1.07 \pm 0.06$ & $1.09 \pm 0.06$ \\
Pituitary gland (mg) & $7.75 \pm 0.75$ & $7.30 \pm 0.95$ \\
Liver & $11.76 \pm 1.35$ & $12.88 \pm 1.12$ \\
Right kidney & $1.05 \pm 0.10$ & $1.06 \pm 0.06$ \\
Left kidney & $1.05 \pm 0.10$ & $1.08 \pm 0.08$ \\
Lung & $1.36 \pm 0.15$ & $1.30 \pm 0.10$ \\
Right testis & $1.30 \pm 0.15$ & $1.30 \pm 0.09$ \\
Left testis & $1.27 \pm 0.18$ & $1.30 \pm 0.10$ \\
Left epididymis & $0.43 \pm 0.05$ & $0.43 \pm 0.02$ \\
Prostate & $0.27 \pm 0.04$ & $0.27 \pm 0.02$ \\
Seminal vesicle & $0.33 \pm 0.04$ & $0.33 \pm 0.03$ \\
\hline Resits are express
\end{tabular}

Results are expressed in mean \pm S.D. $\mathrm{P}>0.05$. (Control $\mathrm{N}=12$; Treated $\mathrm{N}=10)$

Table 3. Weights of vital and reproductive organs of control and Rosmarinus officinalis-treated adult male Wistar rats with twice the dose during exposure of five days and death at three days after the end of treatment

\begin{tabular}{l|l|l}
\hline \multicolumn{1}{c|}{ Weights } & \multicolumn{2}{c}{ Groups (g) } \\
\cline { 2 - 3 } & Control & Treated \\
\hline Brain & $1.15 \pm 0.03$ & $1.15 \pm 0.05$ \\
Pituitary gland (mg) & $8.58 \pm 1.73$ & $7.83 \pm 1.27$ \\
Liver & $11.90 \pm 1.58$ & $11.24 \pm 1.59$ \\
Right kidney & $1.08 \pm 0.10$ & $1.04 \pm 0.09$ \\
Left kidney & $1.06 \pm 0.11$ & $1.05 \pm 0.08$ \\
Lung & $1.32 \pm 0.11$ & $1.24 \pm 0.09$ \\
Right testis & $1.35 \pm 0.04$ & $1.28 \pm 0.11$ \\
Left testis & $1.31 \pm 0.06$ & $1.29 \pm 0.07$ \\
Left epididymis & $0.46 \pm 0.02$ & $0.46 \pm 0.03$ \\
Prostate & $0.31 \pm 0.07$ & $0.30 \pm 0.05$ \\
Seminal vesicle & $0.33 \pm 0.03$ & $0.40 \pm 0.03 *$ \\
\hline
\end{tabular}

Results are expressed in mean \pm S.D. $\mathrm{P}<0.05 .(\mathrm{N}=12)$ 


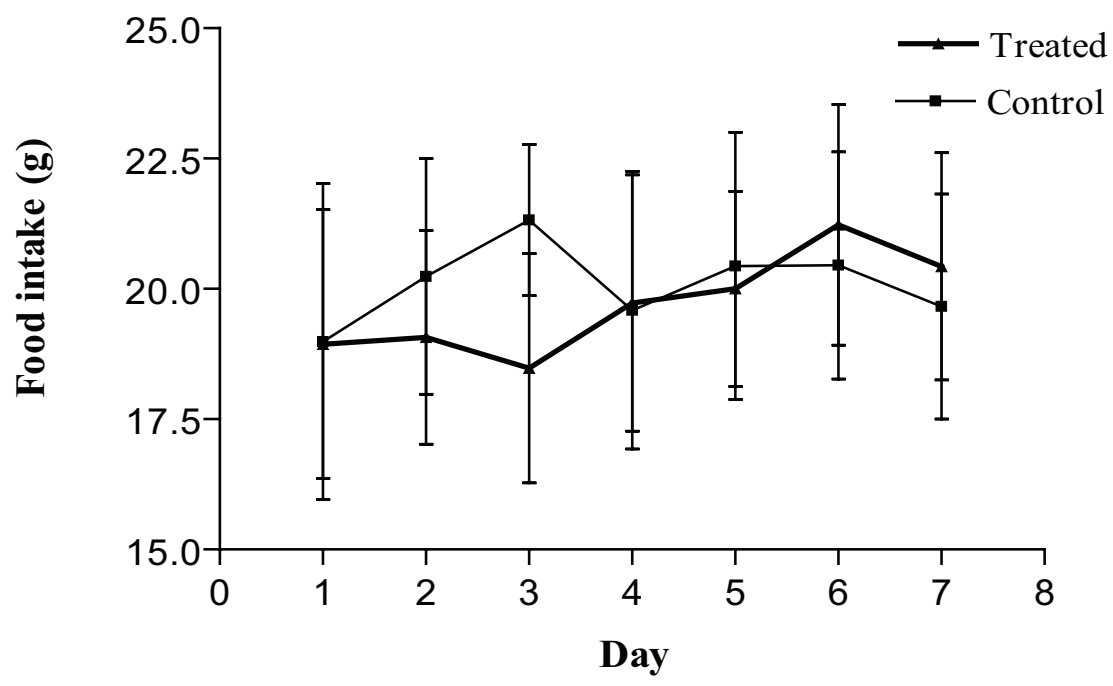

Figure 7. Sperm concentration of the right epididymis cauda of control and $R$. officinalis-treated Wistar rats killed at three (a and c) and 14 days (b) after the end of treatment.

with food consumption (Figures 2, 4 and 6).

The results show that the administration of the lower dose $(291.2 \mathrm{mg} / \mathrm{kg}$ of body weight) of $R$. officinalis with death occurring at three and 14 days after the end of treatment did not produce any significant weight alteration in the organs of the reproductive system, the accessory glands, liver, kidneys, lungs, brain and pituitary gland (Tables 1 and 2). However, the administration of twice the dose $(582.4 \mathrm{mg} / \mathrm{kg}$ of body weight) resulted in a significant weight increase of the seminal vesicle of the treated rats whereas the weights of the other organs analyzed were not significantly altered (Table 3) (Dimech et al., 2006).

An increase in the weight of reproductive organs is under hormonal control and could suggest a disturbance of the reproductive endocrine functions (Elbetieha et al., 2001). The pituitary gland is responsible for the secretion of follicle-stimulating hormone (FSH) and luteinizing hormone ( $\mathrm{LH})$, which act on the testes. Any damage to this gland could interfere with the male reproductive system, thus affecting the production of sex steroid hormones and male gametes (Mahony; Hodgen, 1995). In addition to the endocrine influence, the adverse effect of a substance on the epididymal sperm number is also a potential indicator of reproductive toxicity (Blazak et al., 1985). In this work, despite the weight increase of the seminal vesicle no significant weight gain or loss was detected in the pituitary gland. The cauda epididymis sperm number did not differ between treated and control animals (Figure 7), suggesting that the weight increase of the seminal vesicle is not related to a toxic action of $R$. officinalis extract on the functioning of the pituitary gland.

\section{CONCLUSIONS}

Our preliminary assessment of possible male reproductive toxicity of $R$. officinalis administered to mature male Wistar rats showed an adverse effect on the seminal vesicle but indicates that there are no toxic effects on the testis, epididymis and prostate. No interference with the spermatogenic cycle and consequently with gamete production was detected considering the acute reproductive test protocol employed in this work. However, further studies adopting chronic protocols should be applied to investigate the effect of different doses over several spermatogenic cycles in order to obtain more conclusive results about this plant toxicity and antifertility activity.

\section{ACKNOWLEDGEMENTS}

This research was supported by BIC/UFJF. The authors are grateful to Paulo Sérgio do Carmo for the technical assistance.

\section{REFERENCES}

Abe F, Yamauchi T, Nagao T, Kinjo J, Okabe H, Higo H, Akahane H 2002. Ursolic acid as a trypanocidal constituent in rosemary. Biol Pharm Bull 25: 14851487.

Al-Sereiti MR, Abu-Amer KM, Sen P 1999. Pharmacology of rosemary (Rosmarinus officinalis Linn.) and its therapeutic potentials. Indian J Exp Biol 37: 124130.

Amin A, Hamzer AA 2005. Hepatoprotective effects of Hibiscus, Rosmarinus and Salvia on azathioprineinduced toxicity in rats. Life Sci 77: 266-278.

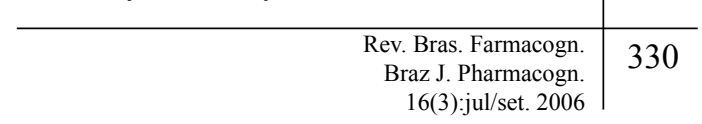


Aruoma OI, Halliwell B, Aeschbach R, Löligers J 1992. Antioxidant and pro-oxidant properties of rosemary constituents: carnosol and carnosic acid. Xenobiotica 22: $257-268$

Barbosa-Filho JM, Medeiros KCP, Diniz MFFM, Batista LM, Athayde-Filho PF, Silva MS, Cunha EVL, Almeida JRGS, Quintans-Júnior LJ 2006. Natural products inhibitors of the enzyme acetylcholinesterase. Rev Bras Farmacogn 16: 258-285.

Bhargava SK 1989. Antiandrogenic effects of a flavonoid rich fraction of Vitex negundo seeds: a histological and biochemical study in dogs. $J$ Ethnopharmacol 27: 327-339.

Blazak WF, Ernst TL, Stewart BE 1985. Potential indicators of reproductive toxicity: testicular sperm production and epididymal sperm number, transit time, and motility in Fischer 344 rats. Fund Appl Toxicol 5: 1097-1103

Born SL, Caudill D, Smith BJ, Lehman-Mckeeman LD 2000 In vitro kinetics of coumarin 3,4-epoxidation: application to species differences in toxicity and carcinogenicity. Toxicol Sci 58: 23-31.

Camargo MTA 1985. Medicina Popular: aspectos metodológicos para pesquisa, garrafada, objeto de pesquisa, componentes medicinais de origem vegetal, animal e mineral. São Paulo: Almed, p. 47-49.

Chan PK, Hayes AW 1994 Acute toxicity and eye irritancy. In: Hayes AW (Ed.) Principles and methods of toxicology. 3 ed. New York: Raven Press, p. 579647.

Clegg ED, Perreault SD, Klinefelter, GR 2001 Assessment of male reproductive toxicity. In: Hayes AW (Ed.) Principles and methods of toxicology. 4 ed. Philadelphia: Taylor \& Francis, p. 1263-1300.

Cruz FG, Roque NF, Giesbrecht AM, Davino SC 1996. Antibiotic activity of diterpenes from Mikania triangularis. Fitoterapia 67: 189-90.

Damasco DC, Lemonica IP 1999. Embriyotoxicity and antiimplantation effects of rosemary. (Rosmarinus officinalis L.) extract in pregnant rats within preimplantation period. Rev Bras Toxicol 12: 4754.

Dias P, Foglio MA, Possenti A, Carvalho JE de 2000. Antiulcerogenic activity of crude hydroalcoholic extract of Rosmarinus officinalis L. $J$ Ethnopharmacol 69: 57-62.

Dimech GS, Gonçalves ES, Araújo AV, Arruda VM, BaratellaEvêncio L, Wanderley AG 2006. Avaliação do extrato hidroalcoólico de Mentha crispa sobre a performance reprodutiva em ratos Wistar. Rev Bras Farmacogn 16: 152-157.

Dmitriev M, Rastyannikov E, Akimov Y, Mlysheva A 1988. Chromatrography-mass spectrometry of volatiles from plants of Southern Crimea. Rastitel'nye Resursy 24: 81-85.

Elbetieha A, Bataineh H, Darmani H, Al-Hamood MH 2001. Effects of ling-term exposure to manganese chloride on fertility of male and female mice. Toxicol Lett 119: 193-201.

Fahim FA, Esmat AY, Fadel HM, Hassan KF 1999. Allied studies on the effect of Rosmarinus officinalis L. on experimental hepatotoxicity and mutagenesis. Int $J$ Food Sci Nutr 50: 413-427.
Funke I, Melzig MF 2006. Traditionally used plants in diabetes therapy - phytotherapeutics as inhibitors of $\alpha$ amylase activity. Rev Bras Farmacogn 16: 1-5.

Guilbert N, Bezanger L 1970. Flavonoids of some medicinal labiate (rosemary, peppermint, garden sage). Plantes Medicinales et Phytotherapie 4: 92-107.

Haloui M, Loudec L, Michel JB, Lyoussi B 2000. Experimental diuretic effects of Rosmarinus officinalis and Centaurium erythraea. J Ethnopharmacol 71: 465472.

Hoefler C, Fleurentin J, Mortier F, Pelt JM, Guillemain J 1987. Comparative choleretic and hepatoprotective properties of young sprouts and total plant extracts of Rosmarinus officinalis in rats. J Ethnopharmacol 19: $133-143$

Huang MT, Ho CT, Wang ZY, Ferraro T, Lou YR, Stauber K, Ma W, Georgiadis C, Laskin JD, Conney AH 1994. Inhibition of skin tumorigenesis by rosemary and its constituents carnosol and ursolic acid. Cancer Res 54: 701-708

Keeler RF 1990. Early embryonic death in lambs induced by Veratrum californicum. Cornell Veterinary 80: 302307.

Kimmel GL, Clegg ED, Crisp TM 1995. Reproductive toxicity testing: A risk assessment perspective. In: Witorsch RJ (Ed) Reproductive toxicology. 2 ed. New York: Raven Press, p. 75-98.

Klinefelter GR, Laskey JW, Roberts NR, Slott V, Suarez JD 1990. Multiple effects of ethane dimethanesulfonate on the epididymis of adult rats. Toxicol Appl Pharmacol 105: 271-287.

Larrondo JV, Agut M, Calvo-Torras MA 1995. Antimicrobial activity of essences from labiates. Microbios 82: 171-172.

Laszlo H, Henshaw PS 1954. Plant materials used by primitive people to affect fertility. Science 119: 626-629.

Lemonica IP, Damasceno DC, Di Stasi LC 1996. Study of the embryotoxic effects of an extract of rosemary (Rosmarinus officinalis L.). Braz J Med Biol Res 29: 223-227.

Lima IO, Oliveira RAG, Lima EO, Farias NMP, Souza EL 2006. Atividade antifúngica de óleos essenciais sobre espécies de Candida. Rev Bras Farmacogn 16: 197-201

Linder RE, Strader LF, Rehnberg GL 1990. Effect of acute exposure to boric acid on the male reproductive system of the rat. J Toxicol Environ Health 31: 133146.

Linder RE, Strader LF, Slott VL, Suarez JD 1992. Endpoints of spermatotoxity in the rat after short duration exposures to fourteen reproductive toxicants. Reprod Toxicol 6: 491-505.

Linder RE, Klinefelter GR, Strader LF, Suarez JD, Dyer CJ 1994. Acute spermatotoxic effects of bromoacetic acids. Fund Appl Toxicol 22: 422-430.

Mahmoud AA, Al-Shihry SS, Son BW 2005. Diterpenoid quinines from rosemary (Rosmarinus officinalis $\mathrm{L}$.). Phytochemistry 66: 1685-1690.

Mahony MC, Hodgen GD 1995. Toxic effects on the hypothalamus-anterior pituitary-gonadal axis, control on the male and female reproductive system, and related issues. In: Witorsch RJ (Ed.) Reproductive toxicology. 2 ed. New York: Raven 
Press, p. 195-213.

Mangena T, Muyima NY 1999. Comparative evaluation of the antimicrobial activities of essential oils of Artemisia afra, Pteronia incana and Rosmarinus officinalis on selected bacteria and yeast strains. Lett Appl Microbiol 28: 291-296.

Maris L, Giovanni O 1958. Isolation and constitution of rosmarinic acid from Rosmarinus officinalis. Ricerca in Science 28: 2329-2333.

Martins ER, Castro DM, Castellani DC, Dias JE 2000. Plantas Medicinais. Viçosa: Editora UFV, p. 70-73.

Mason JM, Kang YJ 1994. Test methods for assessing female reproductive and developmental toxicology. In: Haye AW (Ed.) Principle and methods of toxicology. 3 ed., New York: Raven Press, p. 980-1037.

Mengue SS, Mentz LA, Schenkel EP 2001. Uso de plantas medicinais na gravidez. Rev Bras Farmacogn 11: 21-35.

Mooradian AD, Morley JE, Korenman SG 1987. Biological actions of androgens. Endocrine Rev 8: 1-27.

Moraes GES 1994. Espermocitograma. Porto Alegre: Editora Médica Missau, p. 61-93.

Norton S 1996. Toxic effects of plants. In: Klaassen CD (Ed) Casarett and Doull's Toxicology: The Basic Science of Poisons. New York: Mcgraw-Hill, p. 841-854.

Ruppelt BM, Pereira EFR, Gonçalves LC, Pereira NA 1990. Abordagem farmacológica de plantas recomendadas na medicina folclórica como antiofídicas. I Atividades analgésica e antiinflamatória. Rev Bras Farm 71: 54-56.

Santos CAM, Torres KR, Leonart R 1988. Plantas Medicinais (herbarium, flora et scientia). 2 ed. São Paulo: Ícone, p. 29.

Singletary KW, Nelshoppen JM 1991. Inhibition of 7,12dimethylbenz[a]antracene (DMBA)-induced mammary tumorigenesis and of in vivo formation of mammary DMBA-DNA adducts by rosemary extract. Cancer Lett 60: 169-175.

Sokal RR, Rohlf FJ 1995. Biometry. The principles and practice of statistics in biological research. 3 ed. New York: WH Freeman p. 850.

Sotelo-Félix JL, Martinez-Fong D, Muriel P, Santillán RL, Castillo D, Yahuaca P 2002. Evaluation of the effectiveness of Rosmarinus officinalis (Lamiaceae) in the alleviation of carbon tetrachloride-induced acute hepatotoxicity in the rat. $J$ Ethnopharmacol 81: 145-154.

Soufir JC, Radique C, Dantec MC, Garner D, Jegou B 1989. Gossypol-induced modifications in the microenvironment of rat epididymal spermatozoa. J Reprod Fertil 86: 427-434.

Sundaram K, Witorsch RJ 1995. Toxic effects on the testes. In: Witorsch RJ (Ed.) Reproductive Toxicology, New York: Raven Press, p. 99-121.

Thorsen MA, Hildebrandt KS 2003. Quantitative determination of phenolic diterpenes in rosemary extracts. Aspects of accurate quantification. $J$ Chromatogr A 995: 119-125.

Tôrres AR, Oliveira RAG, Diniz MFFM, Araújo EC 2005. Estudo sobre o uso de plantas medicinais em crianças hospitalizadas da cidade de João Pessoa: riscos e benefícios. Rev Bras Farmacogn 15: 373380 .
Tsunoda Y, Chang MC 1976. Fertilizing ability in vivo and in vitro of spermatozoa of rats and mice treated with alpha chlorohydrin. J Reprod Fertil 46: 401-406.

Ulubelen A, Ertogrul L, Birman H, Yigit R, Erseven G, Olgac V 1994. Antifertility effects of some coumarins isolated from Ruta chalepensis and R. chalepensis var. latifolia in rodents. Phytother Res 8: 233-236.

Vieira-Filho SA, Duarte LP, Silva GDF, Mazaro R, Stasi LCD 2002. Constituintes químicos e atividade antiespermatogênica em folhas de Austroplenckia populnea (Celastraceae). Rev Bras Farmacogn 12(Supl. 1): 123-124

Vilegas JHY, Marchi E, Lanças FM 1997. Extraction of lowpolarity compounds (with emphasis on coumarin and kaurenoic acid) from Mikania glomerata ("guaco") leaves. Phytochem Anal 8: 266-70.

Yakhontova L, Kuzovkov A 1963. Alkaloids of the Rosmarinus genus. II. Partial structural formula of rosmaricine. Zhurnal Obshchei Khimii 33: 308-309.

Watt JM, Breyer-Branwijk MG 1962. The medicinal and poisonous plants of southern and eastern Africa, Edinburgh: Livinstone,

Working PK, Bus JS, Hamm TE Jr. 1985a. Reproductive effects of inhaled methyl chloride in the male Fischer 344 rat. Toxicol Appl Pharmacol 77: 133-143.

Working PK, Bus JS, Hamm TE Jr. 1985b. Reproductive effects of inhaled methyl chloride in the male Fischer 344 rat. II. Spermatogonial toxicity and sperm quality. Toxicol Appl Pharmacol 77: 144-157.

Zenick H, Clegg ED, Perreault SD, Klinefelter GR, Earl Gray L 1994. Assessment of male reproductive toxicity: a risk assessment approach: In: Hayes AW, (Ed.) Principles and Methods of Toxicology. New York: Raven Press, p. 937-988.

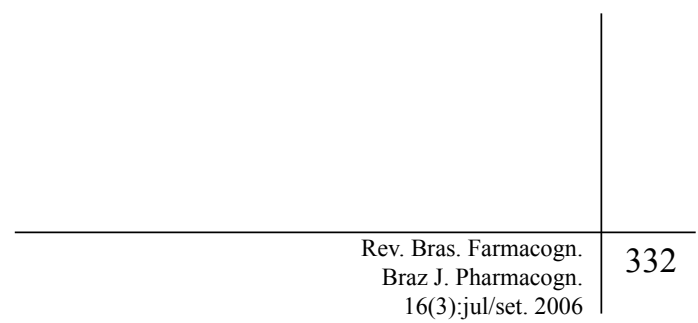

